\title{
Preschool Teacher Opinions on Undesirable Behaviors
}

\author{
Seda ATA, Seda KARAYOL ${ }^{*}$ \\ Preschool Teacher Opinions on Undesirable Behaviors
}

\section{Abstract}

The aim of this research is to identify the preschool teacher opinions on undesirable behaviors in classroom. To this end, 40 preschool teachers were interviewed. Convenience sampling method was used when creating the study group. The research was conducted with qualitative case study. The preschool teachers were asked about their opinions on undesirable behaviors in classroom with the semi-structured interview forms. Answers of the teachers were analyzed with the content analysis method. The data obtained were analyzed with the categorical analysis technique. The findings were classified as the most observed undesirable behaviors, short-term undesirable behavior intervention methods and long-term undesirable behavior intervention methods. According to the findings, the most observed undesirable behaviors were "disobedience to instructions". It was seen that the teachers used 9 different short-term intervention methods for undesirable behaviors; they resort to the "carrot-and-stick" method most. The teachers used 17 different short-term intervention strategies and reported that they "looked for solutions together with parents" most.

Key Words: Early Childhood Education, Preschool Teachers' Opinions, Undesirable Behaviors, Classroom Management
Okul Öncesi Öğretmenlerinin İstenmeyen Davranışlar Hakkındaki Görüşleri

Özet

Bu araştırmada, okul öncesi öğretmenlerinin sınıf içinde istenmeyen davranışlara ilişkin görüşlerinin belirlenmesi amaçlanmıştır. Bu doğrultuda 40 okul öncesi öğretmeniyle görüşme gerçekleştirilmiştir. Çalışma grubu oluşturtulurken kolay ulaşılabilir durum örneklemesinden yararlanılmıştır. Araştırma, nitel araştırma yöntemlerinden tekli durum çalışması deseniyle yürütülmüştür. Yarı-yapılandırılmış görüşme formlarıyla okul öncesi öğretmenlerine sınıf içinde istenmeyen davranışlara ilişkin görüşleri sorulmuştur. Öğretmenlerden alınan cevaplar içerik analizi yoluyla çözümlenmiştir. Elde edilen veriler, kategorisel analiz tekniği kullanılarak çözümlenmiştir. Bulgular; en sık karşılaşılan istenmeyen davranışlar, kısa vadeli istenmeyen davranışlara müdahale yöntemleri, uzun vadeli istenmeyen davranışlara müdahale yöntemleri olarak temalandırımıştır. Elde edilen bulgulara göre; öğretmenlerin sınıflarında en sık karşılaştıkları istenmeyen davranışın "yönergelere uymama" olduğu belirlenmiştir. Öğretmenlerin istenmeyen davranışlara yönelik kısa vadeli çözüm önerileri incelendiğinde ise kullanılan 9 farklı strateji olduğu görülmüş, en sık "ödül/ceza" yöntemine başvurduklarını belirtmişlerdir. Öğretmenlerin istenmeyen davranışlara yönelik uzun vadeli çözüm önerileri incelendiğinde ise toplamda 17 farklı stratejinin ifade edildiği görülmüş, en sık "aileyle birlikte çözüm yolları aradıkları"nı dile getirmişlerdir

Anahtar Kelimeler: Okul Öncesi Eğitim, Okul Öncesi Öğretmen Görüşleri, İstenmeyen Davranışlar, Sınıf Yönetimi,

\section{Giriş}

Undesirable behaviors are defined as behaviors which are difficult to deal with and hinder the functioning of classroom and hinder the learning difficult to deal with (Houghton, Wheldall and

\footnotetext{
*Seda ATA, Muğla Sıtkı Koçman Üniversitesi, Eğitim Fakültesi, sedaata@mu.edu.tr, ORCID ID orcid.org / 0000-00030131-4047, Seda KARAYOL, Muğla Sıtkı Koçman Üniversitesi, Eğitim Fakültesi, skaracelik@mu.edu.tr, ORCID ID orcid.org / 0000-0002-9181-3896.
} 
Merrett, 1998; Thompson, 2009). Undesirable behaviors in preschool classrooms seen as failures in sleeping and eating routines, physical and verbal aggressiveness, damage to objects, tantrums, self-harm and defiance (Smith and Fox, 2003; Bear, Cavalier and Manning, 2002). As stated by Özbey and Alisinanoğlu (2009), preschool children exhibit problematic behaviors such as mocking their friends, teasing, bullying and aggressiveness. Behaviors that are most emphasized by teachers include hyperactivity, lack of attention, tantrums, disobedience, attention grabbing behaviors and conflict with peers (Bulut and iflazoğlu, 2007; Campbell, 1995; Dickerson, 2000; Hamre and Pianta, 2001).

Behavioral problems during early childhood affect children's educational lives and may cause them to experience adverse situations in adulthood (Campbell, Spieker, Burchinal and Poe, 2006). If children's behavioral problems are not handled properly, children will have higher risks of going through certain hardships in their social relationships (Bayer et al., 2012; Dunlap et al., 2006; Kim, Arnold, Fisher and Zeljo, 2005; Marchant, Young and West, 2004). In this sense, it can be argued that teachers commonly use proper intervention methods in in-class interaction. As each child has different rates of development and maturation, their developmental characteristics need to be considered when defining the problematic behaviors (Honig, 1997). For instance, although the impulse to explore surroundings is an important feature of young children's development, such behavior usually concerns adults.

Moreover, it may cause conflict between adult and child (Campbell, 1995). Young children's impulse to explore surroundings may present danger to both themselves and others if a proper and safe environment is not provided (Larzelere, Amberson and Martin, 1992).

Teachers should be informed of basic human needs and behaviors that occur when such needs are not met as well as the child development so that they can effectively deal with undesirable behaviors. Preschool teachers who have detailed knowledge on child development can distinguish "childish" behaviors and undesirable behaviors (Fields and Boesser, 2002). Such teachers are also expected to do certain arrangements in the classroom. General conditions of preschool classrooms have positive or negative impact on children's social behaviors. It is particularly expected from teachers to assume supportive attitude toward children. For example, it has been observed that children cannot use strategies that support self-regulation skills but can use them with the help of others (Ross and Conant, 1992; Spivak and Farran, 2016). In short, children need external support to develop their own feelings and behavior (Calkin and Hill, 2007; Morris, Silk, Steinberg, Myers and Robinson, 2007; McClelland and Cameron, 2012). It is accordingly argued that teachers play a critical role in the development of children's social skills in the classroom (Hamre, Pianta, Mashburn and Downer, 2007). When teachers create a classroom setting which support the occurrence of positive behaviors, increase is observed in their participation in activities, self-regulation and social skills (Thompson and Goodman, 2009).

Teachers should assume such attitudes to support children in consideration of their needs (Pianta, 1999; Pianta, Hamre and Stuhlman, 2003). Supportive relationships with their teachers will increase the probability of children to show desirable behaviors (Hamre and Painta, 2001). 
Children who can establish good relationships with their teachers will want to draw attention in a positive manner and pay more attention to what their teachers say and do (Edwards and Raikes, 2002). On the other hand, it is suggested that children with behavioral problems are rejected by their peers, draw their teachers' positive attention less frequently, are able to perform less successfully in the classroom and face the risk of developing a negative school attitude (LeBlanc, Swisher, Vitaro and Tremblay, 2007).

Children who establish secure relationships with their teachers are likely to show fewer undesirable behaviors in preschool classrooms than children who establish insecure or conflicting relationships (Joseph and Strain, 2004). In a preschool classroom where children can feel secure and are supported, they will exhibit fewer undesirable behaviors because they know what and when to do and what is expected from them. Researchers have shown that positive teacher-student relationship functions as a moderator between the early risk elements and problematic behaviors in years to come (Burchinal, Peisner-Feinberg, Pianta and Howes, 2002; Hughes, Cavell and Wilson, 2001; Ladd and Burgess, 2001; Meehan, Hughes and Cavell, 2003). Children will show fewer problematic behaviors once teachers look after them with proper behaviors and provide them with the support they need (Hemmeter, Fox, Jack, Broyles and Doubet, 2007).

Teachers' cordial and supportive relationships with children reinforce their social and academic developments whereas their conflicting attitude increases the prevalence of undesirable behaviors (Runions, 2014). Clear and coherent expectations cause younger children's self-regulation skills to develop and their problematic behaviors to decrease (Powell, Dunlop and Fox, 2006). Once children enjoy what they are interested in, they will exhibit fewer problematic behaviors (Sugai and Horner, 2002). It is argued that problematic behaviors will be significantly reduced with distinct expectations of in-class behaviors and physical regulation in a classroom where participation in activities and peer interaction are supported and desirable behaviors attract more attention (McCabe and Frede, 2007; Powell, Dunlop and Fox, 2006). For instance, children going through negative interaction with their parents are more likely to exhibit problematic behaviors in classroom (Patterson, Reid and Eddy, 2002). If combined with the inexperience of teacher in case of problematic situations, it might cause children to maintain such negative interaction with teacher (Stormont, Beckner, Mitchell and Richter, 2005). Studies have shown that teachers react more negatively to children who exhibit problematic behaviors (Barnett and Boocock, 1998). Consequently, such children get fewer learning opportunities, take part in in-class activities less frequently and might miss the opportunity to have school preparedness skills as they are in less negative interaction with their teachers (Raver and Knitzer, 2002).

It can be argued in the light of abovementioned research results that teachers are important figures to undesirable behaviors exhibited by children. In this context, it is considered important what teachers think of children's undesirable behaviors and to identify their attitudes toward such behaviors. When reviewing the related literature, there is limited number of studies on practices of preschool teachers against undesirable behaviors in classroom. It is accordingly thought that this 
Seda ATA | Seda KARAYOL

research will be beneficial. This study aims to explore preschool teacher opinions on undesirable student behaviors.

\section{Research Method}

The research was designed in accordance with the case study method which is a qualitative research method. Case studies are defined as studies in which researchers put the questions "Why?" and "How?" in the center and want to examine the research matter in depth and in detail (Yin, 2009).

There are different types of case study. The single case study was utilized in this research. It is suggested that the single case study pattern can be used when a single case is to be studied within its own social contexts and within the limitation of stakeholders without any comparison (Yin, 2009). The single case addressed in this research is preschool teachers' opinions on undesirable behaviors.

\subsection{Research Sample}

Convenience sampling which is a purposive sampling method was used in this research. The point with this method is to have an opinion of a certain domain by studying average situations (Yıldııım and Şimşek, 2013). This research was conducted with 48 preschool teachers (37 women, 11 men) working in Muğla province in the Fall term of the 2016-2017 academic year. 18 preschool teachers have bachelors and 30 preschool teachers have associate degree. Ages of the teachers varied between 24 and 54 years. All participants were volunteers who, at the time of the study, were employed in private preschools. For confidentiality purposes, the names of the participants were not disclosed but mentioned in codes $(\mathrm{T} 1, \mathrm{~T} 2 \ldots)$ in the research.

\subsection{Data Collection Instrument}

Semi-structured interview form was used as data collection tool. In order to obtain comparative results, the preferred semi-structured interview form was developed for teachers in accordance with the research questions and the literature. It has been presented to the opinion of the field experts to check on the extent to which the prepared interview form serves the purpose. To ensure the internal validity of the interview form, opinions of 3 field experts were received to do necessary corrections. Comprehensibility of the questions in the interview form was checked in the interviews made with 3 teachers. Finalized in the pilot application, the interview form was composed of 3 open-ended questions. The data were collected with a voice recorder upon the consent of the voluntary teachers. Each interview lasted about 20 minutes.

Questions were asked in the semi-structured interview to find out about the opinions of the teachers on undesirable behaviors. To that end, the following open-ended questions were asked to the teachers:

1. What are the undesirable behaviors you observe in your classroom most? 
2. Which methods do you use to solve those undesirable behaviors in your classroom in the short term?

3. What are the long-term solutions you use to decrease the prevalence of undesirable behaviors in your classroom?

\subsection{Data Collection and Data Analysis}

The interviews with the teachers were recorded with the consent of the participants to avoid data loss. The voice records were transcribed into written documents. Next, the dataset transcribed into written documents were compared with the voice records, and missing or incorrect parts were edited. The data were subjected to both descriptive and content analyses. The interviews were repeated with the participant teachers for the findings achieved in the analysis (Fraenkel, Wallen and Hyun, 2012). Hence, it was ensured that the findings were confirmed by the participants themselves, and it was tested whether there was a change in their opinions. The purpose is to include participants in the data analysis process to increase the internal validity of the findings. First, the data were written out, processed in accordance with the specified themes and the findings were interpreted with direct citations. The following steps were followed respectively in the analysis of the research data: data encoding, theme finding, organization of codes and themes, definition and interpretation of the findings. Raw data obtained in the interviews were studied in detail to omit redundant statements. The remaining statements were encoded in a general framework on the sentence level. Each new sentence was created in comparison with the current code sentence by adding either to a new code sentence or a current code sentence frequency. As new codes were created and improved, a code list was formed and updated. Codes were combined and their similar characteristics were found in an effort to form the themes. Similarities and differences of the codes were identified, and accordingly, the codes which were deemed associated with each other were combined (Creswell, 2003; Straus and Corbin, 1998; Yıldırım and Şimşek, 2013) to find the themes. Once the codes were formed and the themes were found, the researchers gathered the data they collected together (Yıldırım and Şimşek, 2013). At this point, the data were finally defined to be described so that the reader can comprehend them. Participants' statements were partially and directly quoted to ensure that the research data were interpreted in a more easy and reliable way. To achieve the data reliability, the records and the written versions were examined by another researcher and the examination was compared with the written versions in the hands of the researchers (Yıldırım and Şimşek, 2008). In this research, the consistency rate between the researchers in the description of the answers provided by the preschool teachers was found to be $87.33 \%$.

\section{Findings}

Findings achieved in the interviews with 48 preschool teachers were directly quoted and tabularized in themes, numbers and percentage (\%) in this section. 
Seda ATA | Seda KARAYOL

Table 1. Teacher Opinions On The Most Observed Undesirable Behaviors In Their Classrooms

\begin{tabular}{lll}
\hline \hline Sub- themes & $n$ & $\%$ \\
\hline Disobedience to instructions & 15 & 31 \\
Aggressiveness & 14 & 29 \\
Selfishness & 10 & 21 \\
Distractibility & 9 & 19 \\
Introversion & 5 & 10 \\
Eating problems & 5 & 10 \\
Speaking too loud & 3 & 6 \\
Crying to have something done & 3 & 6 \\
Sanitation and etiquette & 1 & 2 \\
Complaining & 1 & 2 \\
Lying & 1 & 2 \\
No problems & 1 & 2 \\
\hline
\end{tabular}

It is seen in Table 1 that majority of the undesirable behaviors most observed by the preschool teachers in their classrooms were "disobedience to instructions" ( $n=15,31 \%)$ and "aggressiveness" ( $n=14 ; 29 \%)$. These were followed by "selfishness" ( $n=10 ; 21 \%)$ and "distractibility" ( $n=9$; 19\%). The least observed undesirable behaviors were "introversion" ( $n=5 ; 10 \%)$, "eating problems" $(n=4 ; 8 \%)$, "speaking too loud" ( $n=3 ; 6 \&)$ "sanitation and etiquette" $(n=3 ; 2 \%)$, "complaining" $(n=1$; $2 \%$ ) and "lying" ( $n=1 ; 2 \%)$. One of the teachers stated that he/she did not observe any undesirable behaviors.

Some of the participant teachers $(n=15)$ stated that they observed "disobedience to instructions" most frequently. Emphasizing that children who do not follow classroom rules in the activities during the term reduce their efficiency, too, and have a negative impact on other children's performance, one of these teachers provided the following statement:

"I frequently see children who do not listen to me and do disobey the instructions in my classroom most, and it is always my highest concern throughout the year. Even though I try to say that it may be an adaptation period for the children, it may be very hard to work with children who disobey instructions." (T8, Woman) 
Some of the participant teachers ( $n=14$ ) said that aggressiveness was most observed by them. Accordingly, one of these teachers stated that they observe this in game behaviors more frequently:

"No matter how frequently I tell children to be respectful to each other particularly in game environments, I commonly see that some of the aggressive children hit their friend, I am afraid." (T4, Man)

Five participant teachers said that they observed eating problems most, and one of them provided the following statement:

"The behavior which I observe most and tires me most is to deal with children's eating problems. The pressure laid on us by parents and the fact that their children have no regular eating habit are frequent problems we have in our classrooms." (T38, Woman)

Table 2. Short-Term Solutions Used By Teachers For Undesirable Problems

\begin{tabular}{lll}
\hline \hline Sub- themes & $n$ & $\%$ \\
\hline Carrot-and-stick & 23 & 48 \\
Talking about the problem & 18 & 38 \\
Verbal warning & 14 & 29 \\
Cooperation with parents & 11 & 23 \\
Leading the child to attention-grabbing matters & 10 & 21 \\
Observation & 5 & 10 \\
Receiving professional help & 4 & 8 \\
Assigning with responsibility & 3 & 6 \\
Ensuring that the child takes his/her friends as model & 1 & 2 \\
\hline
\end{tabular}

According to Table 2, about half of the participant teachers resorted to the "carrot-and-stick" $(n=23 ; 48 \%)$ method. They also stated that they preferred methods such as "talking about the problem" ( $n=18 ; 38 \%)$, "verbal warning" ( $n=14 ; 29 \%)$, "cooperation with parents" ( $n=11 ; 23 \%)$, and "leading the child to attention-grabbing matters" ( $n=14 ; 29 \%)$. It is seen that the teachers also used methods such as "observation" ( $n=5 ; 10 \%)$, "receiving professional help" ( $n=4 ; 8 \%)$, and "assigning with responsibility" ( $n=3 ; 6 \%)$. One of the teachers stated that "he/she ensured that the child took his/her friends as model".

Majority of the participant preschool teachers $(n=23)$ stated that intervention used by them in the short term right away in case children showed undesirable behaviors was the carrot-and-stick method and it was the most effective method in terms of reestablishing the order of the class- 
room. One of the teachers emphasized that carrot-and-stick is a very advantageous method through which teacher can decide whether that certain behavior is to be shown:

"At the beginning of the academic year, even though I have some trouble during children's adaptation period, I tell children that each behavior of theirs will have positive or negative consequences. In this awareness, the child can say, 'If I upset my teacher and hurt my friends, I cannot be in the activities and will be forced to watch them from the distance.' What I pay attention to most when I use this system is to give the same reactions to each good or bad behavior. It is not that I ignore a bad behavior and punish another kid who showed the same behavior. I use this method because it is fair." (T31, Woman)

Among the teachers who thought "verbal warning" to be very important $(n=14)$, one of them emphasized that they warn children quickly for their undesirable behaviors:

"The fact that the kid notices me in case of even the smallest negative behavior and my warning 'you cannot go on' works all the time. I used to try to make children be aware of the things in the first years of my career but I have been lately warning children about their behavior right away." (T1, Woman)

While three participant teachers said that they used the method of "assigning with responsibility" against undesirable behaviors, one of them provided the following statement:

"I am unfortunately stuck with the most dynamic kids in my classroom every year. Once I notice that these kids will hurt their friends, I assign them with tasks such as asking them for an object in the classroom and making them take a more active role in a game. This way, the kid strives to meet that responsibility instead of exhibiting the problematic behavior" (T11, Man)

Table 3. Long-Term Solutions Used By Teachers To Decrease The Prevalence Of Undesirable Be-

\begin{tabular}{lll}
\hline \hline Sub- themes & haviors & \\
\hline Cooperation with parents & 33 & 69 \\
Professional help & 17 & 35 \\
Attention-grabbing activities & 15 & 31 \\
Leading the child to different activities & 9 & 19 \\
Reducing the number of objects in classroom & 7 & 15 \\
Carrot and stick & 5 & 10 \\
Parental training & 4 & 8 \\
Classroom rules & 4 & 8 \\
Reducing the classroom size & 2 & 4 \\
\hline
\end{tabular}




\begin{tabular}{lll}
\hline Cooperation with school administration & 2 & 4 \\
Rich materials & 2 & 4 \\
Providing the child with the sense of responsibility & 2 & 4 \\
Not stigmatizing the child & 1 & 2 \\
Assessing each child differently & 1 & 2 \\
Assistant personnel for teacher & 1 & 2 \\
Making the child feel valuable & 1 & 2 \\
It is not possible to do anything & 1 & 2 \\
\hline
\end{tabular}

According to Table 3, majority of the participant teachers resorted to the "cooperation with parents" ( $n=33 ; 69 \%)$. The teachers reported that they used the methods of "professional help" ( $n=17 ; 35 \%)$, "attention-grabbing activities" ( $n=15 ; 31 \%)$, "leading the child to different activities" $(n=98 ; 19 \%)$, "reducing the number of objects in classroom" ( $n=7 ; 15 \%)$, "carrot and stick" ( $n=5$; $10 \%)$, "parental training" ( $n=4 ; 8 \%)$, and "classroom rules" $(n=4 ; 8 \%)$. Very few of the participant teachers stated that they would benefit from different methods. These methods included "reducing the classroom size" ( $n=2 ; 4 \%)$, "cooperation with school administration" ( $n=2 ; 4 \%)$, rich materials" ( $n=2 ; 4 \%)$, "assigning with responsibility" ( $n=2 ; 4 \%)$, "not stigmatizing the child" $(n=1 ; 2 \%)$, "assessing each child differently" ( $n=1 ; 2 \%)$, "assistant personnel for teacher" ( $n=1 ; 2 \%)$, and "making the child feel valuable" ( $n=1 ; 2 \%)$, respectively. One of the participant teachers stated that "it is not possible to do anything" in the long term for undesirable behaviors in classrooms.

Majority of the participant teachers ( $n=33$ ) reported that they used the method of "cooperation with parents" in the long term against undesirable behaviors observed in classrooms. One of those teachers provided the following statement:

"I think parental support needs to be received to find realistic solutions to children's problems. No matter what we do in the classroom, it is sometimes not possible for the child to give up a certain behavior. Therefore, parents need to address that problem along with their children outside the school as well. We cannot do anything in the long term if parents expect everything from us... I definitely use the method of cooperation with parents." (T28, Woman)

Some of the participant teachers $(n=17)$ emphasized that problematic behaviors in classrooms are not something that teacher "can solve on their own", and one of them said the following:

"We come to such a point that we cannot get to perform activities with the children in a healthy way as we deal with problematic behaviors of others. And we are talking about long-term solutions. If we really want to help the children, we should be offered professional help. I ask the school counselor for help in repetitive problems. I benefit from the fact that the counselor makes observations in my classroom and deal with the child one on one." (T5, Man) 
Two participant teachers stated that the reason for problematic behaviors was generally "missing materials and toys", one of them reported as follows:

"I think that the disorder in the classroom does not occur when materials are complete in the classroom. Therefore, we can say that problematic behaviors are shown scarcely or not at all in a classroom full of materials. If I have missing materials in my classroom and when I complete them, I see the children are in harmony both with me and themselves." (T17, Woman)

\section{Discussion and Conclusion}

In this section, the research findings are discussed in the light of other research results in the related literature in an effort, and certain recommendations are made in accordance with the results achieved in this research.

The participant teachers reported 11 different types of undesirable behaviors in the research. The most observed undesirable behavior as stated by the participant teachers was "disobedience to instructions". Dinçer and Akgün (2015) stated in their study with preschool teachers that the preschool teachers working early age group might have encountered problems due to disobedience to instructions in regard to classroom management. This might be the case because teachers cannot comprehend personality traits of children and cannot use proper instructions with them (Kapucuoğlu Tolunay, 2008).

Other most observed undesirable included "aggressiveness", "selfishness", and "distractibility" respectively. Scuffles, occasional discords and fights frequently observed during childhood are not enough to characterize a child as aggressive. In the cases where aggressiveness is continuous and shown in purpose, it needs to be handled as a problem, and proper supports such as reinforcing children's social skills should be presented to them. Then, teachers need to have strategies of solutions to undesirable behaviors (Erbaş and Özkan, 2010; Uysal, Altun and Akgün, 2010). It can be argued that this research finding coincides with the results of the studies where teachers defined hyperactivity, lack of attention, tantrums, disobedience, attention grabbing behaviors and conflict with peers as undesirable behaviors (Bulut and iflazoğlu, 2007; Campbell, 1995; Dickerson, 2000; Hamre and Pianta, 2001).

In a similar study conducted by Sadık (2002), the participant teachers defined the most observed problematic behaviors as noise, indifference, complaining, interrupting, bothering others, not sitting properly and hurting others. In preschool period during which egocentrism is intensive, it is observed that children frequently conflict with each other. Hence, several problematic behaviors shown by children should be perceived as a part of their developments, but observation of children should not be neglected, either. Behaviors such as "distractibility", "introversion", "eating problems", "speaking too loud", "crying to have something done" were described to be undesirable behaviors by the teachers.

As for the short-term solution proposals of the preschool teachers for undesirable behaviors, 9 different strategies in total were mentioned. In this research, the preschool teachers stated that 
they resorted to the "carrot-and-stick" method in regard to the precautions they took for solving the problematic behaviors in their classrooms. According to the relevant literature, it is generally known that teachers use the carrot-and-stick method in a traditional approach to undesirable student behaviors (Sipahioğlu, 2008; Çankaya and Çanakçı, 2011; Aydın, 2012). It can be argued that this finding is in parallel with a research study performed by Öztürk and Gangal (2014) who explored that the participant teachers used the traditional methods (carrot-and-stick) more frequently. Also in parallel with this finding, the research carried out by Akar, Tantekin Erden, Tor and Şahin (2010) with 19 basic education teacher concluded that the teachers were using the carrotand-stick method. This might prevent children from acquiring certain habits which would increase auto-control on their own behaviors.

The preschool teachers stated that the most used methods by them were "talking to childrenverbal warning", "cooperation with parents", and "leading the child to attention-grabbing matters" respectively. "Verbal warning" method was the second most used method by the preschool teachers against undesirable behaviors. This finding coincides with the results of the studies which observed that the teachers were using verbal warnings against undesirable behaviors (Akgün, Yarar and Dinçer, 2011; Uysal, Akbaba-Altun and Akgün, 2010; Yüksel, 2006; Kapucuoğlu, Tolunay, 2008; Yıldı, 2006 Denizel Güven and Cevher, 2005: Can and Baksi, 2014). The most used shortterm methods against undesirable behaviors were found to be "leading the child to attentiongrabbing matters", "observation", "professional help", "assigning with responsibility", and "ensuring that the child takes his/her friends as model" respectively.

As for the long-term solution proposals of the preschool teachers for undesirable behaviors, 17 different strategies in total were mentioned. The preschool teachers said that "they looked for solutions with parents" most frequently. This method was followed by "professional help" and "using attention-grabbing activities". Other methods included "leading the child to different activities", "reducing the number of objects in classroom" and "carrot-and-stick" respectively.

Şahin, Tantekin-Erden and Akar (2011) emphasized in their study conducted with preschool teachers working with 3-6-year-old groups that classroom size is an important factor in classroom management. On the other hand, Denizel Güven and Cevher (2005) found no significant difference in preschool teachers' classroom management skills by the variable of classroom size. The data obtained in this research show that only two of the participant teachers state that reducing the classroom size could be used in the long-term solution of undesirable behaviors.

Parsonson (2012) stated that positive strategies used by teachers such as encouraging and drawing attention to positive behavior increase desirable behaviors while decreasing undesirable behaviors. However, it was found in this research that the teachers looked for the solutions to the problems in their classrooms with the help of off-class partners. It can be argued in the light of this finding that preschool teachers make less effort in resorting to certain behavioral intervention programs they can apply in classroom or practices that support children social skills. 
In a research study conducted by Özen Altınkaynak, Uysal Bayrak, Taşkın and Akman (2018) with 22 preschool teachers, they found that ways of communication such as individual interviews, affection, interest, and empathy were used by very few teachers against undesirable behaviors.

Moreover, it was observed that the teachers were using four common strategies both in the short and long term against undesirable behaviors. These were "assigning with responsibility", "carrot-and-stick", "cooperation with parents" and "professional help". It can be said that "assigning children with responsibility" is a positive method which was used by few teachers. It is possible to say that different responsibilities that can be given to children for changing their undesirable behaviors in the classroom will contribute to the development of their social skills. It was observed that great numbers of the participant teachers were using the "carrot-and-stick" method. One of the possible problems to be caused by this case is that healthy development of children's selfregulation skills is prevented.

In preschool education, it is recommended that school-parents cooperation is managed to support both children's development and the attainments to be acquired in preschool. Although receiving the support of both parents and professionals is regarded as important strategies in the first place, it has been observed that these two strategies are underlain by the fact that teachers expect others to find solutions to undesirable behaviors directly instead of starting a process of solution to the problem based on communication and cooperation. It can be argued that the preschool teachers who participated in this research particularly expect help from parents instead of their own roles and responsibilities in the emergence and elimination of undesirable behaviors both in the short and long term.

It is known that communication and cooperation between teacher and parents are important elements for a quality preschool education. However, it was found that the participant teachers asked the parents to talk to their children so that they would not exhibit the same undesirable behavior in the future rather than taking steps to cooperate with parents against undesirable behaviors.

Roseth, Pellegrini, Dupuis, Bohn, Hickey, Hilk and Peshkam (2008) examined the effect of teacher intervention on children's conflict-solving skills. It was concluded that teacher intervention hindered the children's conflict-solving skills. It is generally known that teachers take on a traditional approach in the classroom. Another explanation made for this case is the result achieved in the research carried out by Dobbins and Higgins (2010). In their research, it was observed that the undergraduate education the participant teachers had received was not on a sufficient level for social skills education. Based on this result, it can be argued that the teachers feel incompetent at how to support children's social skills.

The following recommendations were made in accordance with the findings obtained in the research.

Instead of the traditional methods used by preschool teachers, awareness activities could be performed to support children's social and emotional development. 
Mixed research studies can be carried out to identify the strategies used by preschool teachers against undesirable behaviors in their classrooms.

Behavior modification programs can be performed by preschool teachers for undesirable behaviors within the scope of an in-service training.

It can be ensured that the Classroom Management course given in the undergraduate program of Preschool Teaching is instructed by preschool education experts.

In addition, it is recommended to develop regular counseling programs for teachers in our country based on the research results stating that counseling for teachers (MTP- My Teaching Partner) to support teacher-student relationship contributes to a positive and supportive classroom setting (Pianta, Mashburn, Downer, Hamre, and Justice, 2008; Downer, Pianta, Fan, Hamre, Mashburn, and Justice, 2011).

\section{Kaynaklar}

Akar, H., Tantekin Erden, F., Tor, D. and Şahin, i. T. (2010). Study on teachers' classroom management approaches and experiences. Elementary Education Online, 9(2), 792-806.

Aydın, A. (2012). Sınıf Yönetimi [Classroom Management] (15th Edition), Pegem Akademi Yayınları, Ankara.

Barnett, W. S. \& Boocock, S. S. (Eds.). (1998). Early Care and Education for Children in Poverty: Promises, Programs, and Long-Term Results. SUNY Press.

Bayer, J. K., Ukoumunne, O. C., Mathers, M., Wake, M., Abdi, N. \& Hiscock, H. (2012). Development of children's internalising and externalising problems from infancy to five years of age. Australian and New Zealand Journal of Psychiatry, 46, 659-668.

Bear, G. G., Cavalier, A. R. \& Manning, M. A. (2002). Best practices in school discipline. In A. Thomas \& J. Grimes (Eds.), Best Practices in School Psychology (4th ed., pp. 977991). Bethesda, MD: National Association of School Psychologists.

Bulut, M. S. and íflazoğlu, A. (2007). Anasınıfı öğretmenleri ile öğretmen adaylarının sınıfta karşılaştıkları problem davranışlar ve bu davranışlara yönelik geliştirdikleri stratejiler: nitel bir çalışma örneği. [Problematic behaviors observed by preschool teachers and preservice teachers in the classroom and strategies developed by them for these behaviors: a qualitative research] Book of Symposium on Present and Future of Preschool Education in the Process of European Union. (Ed. N. Aral and B. Tuğrul). Ya-Pa Yayınları.

Burchinal, M. R., Peisner-Feinberg, E., Pianta, R. \& Howes, C. (2002). Development of academic skills from preschool through second grade: Family and classroom predictors of developmental trajectories. Journal of School Psychology, 40(5), 415-436. 
Seda ATA | Seda KARAYOL

Calkins, S. D., \& Hill, A. (2007). The emergence of emotion regulation: Biological and behavioral transactions in early development. In J. J. Gross (Ed.), Handbook of Emotion Regulation (pp. 229-248). New York: Guilford.

Campbell, S. B. (1995). Behavior problems in preschool children: A review of recent research. Journal of Child Psychology and Psychiatry, 36, 113-149.

Campbell, S. B., Spieker, S., Burchinal, M. \& Poe, M. D. (2006). Trajectories of aggression from toddlerhood to age 9 predict academic and social functioning through age 12. Journal of Child Psychology and Psychiatry, 47, 791-800.

Can, E. and Baksi, O. (2014). Öğrencelerin sınıf içi tutum ve davranışlarının öğretmenlerin sınıf yönetimi başarısına etkisi [Effect of students' in-class attitudes and behaviors on teachers' achievement of classroom management]. Asya Öğretim Dergisi, 2(1), 86-101.

Creswell, J. W. (2003). Research design: Qualitative, quantitative, and mixed method approaches. London: Sage Publications, Inc.

Çankaya, i. and Çanakçı, H. (2011). Sınıf öğretmenlerinin karşılaştıkları istenmeyen öğrenci davranışları ve bu davranışlarla başa çıkma yolları [Undesirable student behaviors observed by classroom teachers and their ways of coping with these behaviors]. Turkish Studies-International Periodical for the Languages, Literature and History of Turkish or Turkic, 6(2), 307-316.

Denizel Güven, E. and Cevher, F. N. (2005). Okul öncesi öğretmenlerinin sınıf yönetimi becerilerinin çeşitlideğişkenler açısından incelenmesi [Examination of preschool teachers' classroom management skills by several variables]. Pamukkale University Faculty of Education Journal, 2(18), 1-22.

Dickerson, C.N. (2000). Teachers' attitudes toward preschool children with disruptive behaviors in the classroom. Unpublished master's thesis, University of California, Irvine.

Dinçer, Ç. and Akgün, E. (2015). Okul öncesi öğretmenleri için sınıf yönetimi becerileri ölçeğinin geliştirilmesi ve öğretmenlerin sınıf yönetimi becerilerinin çeşitli değişkenlerle ilişkisi [Development of a classroom management skills scale for preschool teachers and the relationship between teachers' classroom management skills and several variables], Eğitim ve Bilim, 40(177), 187-201.

Dobbins, N. \& Higgins, K. (2010). An analysis of social skills instruction provided in teacher education and inservice training programs for general and special educators. Remedial and Special Education, 31(5), 358- 367. 
Downer, J. T., Pianta, R. C., Fan, X., Hamre, B., Mashburn, A., \& Justice, L. (2011). Effects of web-mediated teacher professional development on the language and literacy skills of children enrolled in prekindergarten programs. NHSA Dialog, 14, 189-212.

Dunlap, G., Strain, P. S., Fox, L., Carta, J., Conroy, M., Smith, B. J. \& Sowell, C. (2006). Prevention and intervention with young children's challenging behavior: Perspective regarding current knowledge. Behavioral Disorders, 32, 29-45.

Erbaş, D. and Özkan, Yücesoy Ş. (2010). Problem Davranışları Azaltmada Olumlu Davranışsal Destek Uygulamaları: Aile ve Öğretmen El Kitabı [Positive Behavioral Support Practices for Reducing Problematic Behaviors: Parent's and Teacher's Handbook]. Ankara: Maya Akademi Yayıncılık.

Fields, M.V. \& Boesser, C. (2002). Constructive Guidance and Discipline. New Jersey: Pearson Education Inc.

Fraenkel, J. R., Wallen, N. E. \& Hyun, H. H. (2012). How to Design and Evaluate Research in Education (8th ed.). New York, NY: McGraw-Hill.

Hamre, B. K., \& Pianta, R. C. (2001). Early teacher-child relationships and the trajectory of children's school outcomes through eighth grade. Child Development, 72(2), 625638.

Hemmeter M. L., Fox L., Jack S., Broyles L. \& Doubet S. (2007). A program-wide model of positive behavior support in early childhood settings. Journal of Early Intervention, 29, 337-355.

Honig, A. S. (1997). Infant temperament and personality: What do we need to know? Montessori Life, 9(3), 18-21.

Houghton, S., Wheldall, K. and Merrett, F. (1988). Classroom behavior problems which secondary school teachers say they find most troublesome. British Educational Research Journal, 14, 297-312.

Hughes, J., Cavell, T. \& Willson, V. (2001). Further support for the developmental significance of the quality of the teacher-student relationship. Journal of School Psychology, 39, 289-302.

Joseph, G. E. \& Strain, P. S. (2004). Building positive relationships with young children. Young Exceptional Children, 7, 21-28.

Kapucuoğlu Tolunay, A. (2008). Sınıf öğretmenlerinin sınıfta karşılaştıkları istenmeyen öğrenci davranışları ve bu davranışlara karşı kullandıkları baş etme yöntemleri [Undesirable student behaviors observed by classroom teachers and their coping methods against these behaviors]. Unpublished Master's Thesis, Uludağ University Institute of Social Sciences: Bursa. 
Seda ATA | Seda KARAYOL

Kim, H.-J., Arnold, D. H., Fisher, P. H. \& Zeljo, A. (2005). Parenting and preschoolers' symptoms as a function of child gender and sex. Child \& Family Behavior Therapy, 27, 23-41.

Ladd, G. W. \& Burgess, K. B. (2001). Do relational risks and protective factors moderate the linkages between childhood aggression and early psychological and school adjustment? Child Development, 72(5), 1579-1601.

Larzelere, R. E., Amberson, T. G. \& Martin, J. A. (1992). Age differences in perceived discipline problems from 9 to 48 months. Family Relations, 41, 192-199.

LeBlanc, L., Swisher, R., Vitaro, F. \& Tremblay, R. E. (2007). School social climate and teachers' perceptions of classroom behavior problems: A 10 year longitudinal and multilevel study. Social Psychology of Education, 10(4), 429-442.

Marchant, M., Young, R. K. \& West, R. P. (2004). The effects of parental teaching on compliance behavior of children. Psychology in the School, 41, 337-350.

McCabe, L. A. \& Frede, E. C. (2007). Challenging Behaviors and the Role of Preschool Education. New Brunswick: National Institute for Early Education.

McClelland, M. M. \& Cameron, C. E. (2012). Self-regulation in early childhood: Improving conceptual clarity and developing ecologically valid measures. Child Development Perspectives, 6, 136-142.

Meehan, B. T., Hughes, J. N. \& Cavell, T. A. (2003). Teacher-student relationships as compensatory resources for aggressive children. Child Development, 74(4), 11451157.

Morris, A. S., Silk, J. S., Steinberg, L., Myers, S. S. \& Robinson, L. R. (2007). The role of family context in the development of emotion regulation. Social Development, 16, 361-388.

Özbey, S. and Alisinanoğlu, F. (2009). Okul öncesi eğitim kurumuna devam eden 60- 72 aylık çocukların problem davranışlarının bazı değişkenlere göre incelenmesi [Examination of problematic behaviors among 60-72-month-old children attending institutions of preschool education by certain behaviors]. The Journal of International Social Research, 2(6), 493-517.

Özen Altınkaynak, Ş., Uysal Bayrak, H., Taşkın, N., and Akman, B. (2018). Çocukların ödül ve ceza algıları ile öğretmenlerin disiplin hakkındaki görüşleri [Children perceptions of reward and punishment and teacher opinions on discipline]. Dicle University, Ziya Gökalp Faculty of Education, 33, 1-12.

Öztürk, Y. and Gangal, M. (2016). Okul öncesi eğitim öğretmenlerinin disiplin, sınıf yönetimi ve istenmeyen davranışlar hakkındaki inançları [Preschool teacher beliefs about 
discipline, classroom management and undesirable behaviors]. Hacettepe University Faculty of Education Journal, 31(3), 593-608.

Parsonson, B. S. (2012). Evidence-based classroom behavior management strategies. Kairaranga, 13(1), 16-23.

Patterson, G. R., Reid, J. B. \& Eddy, J. M. (2002). A brief history of the Oregon Model. In J. B. Reid, G. R. Patterson, \& J. J. Snyder (Eds.), Antisocial behavior in children and adolescents: A developmental analysis and model for intervention (pp. 3-21). Washington, DC: American Psychological Association.

Pianta, R. C. (1999). Enhancing relationships between children and teachers. Washington, DC: American Psychological Association.

Pianta, R. C., Hamre, B. K. \& Stuhlman, M. (2003). Relationships between teachers and children. In W. Reynolds \& G. Miller (Eds.), Comprehensive Handbook of Psychology (Vol. 7) Educational Psychology (pp. 199-234). New York: John Wiley \& Sons.

Pianta, R., Mashburn, A., Downer, J., Hamre, B., \& Justice, L. (2008). Effects of webmediated professional development resources on teacher-child interactions in prekindergarten classrooms. Early Childhood Research Quarterly, 23, 431-451.

Powell, D., Dunlop, G. \& Fox, L. (2006). Prevention and intervention for the challenging behaviors of toddlers and preschoolers. Infants \& Young Children, 19(1), 25-35.

Raver, C. C. \& Knitzer, J. (2002). Ready to Enter: What Research Tells Policy Makers about Strategies to Promote Social and Emotional School Readiness among Three and Four-Year-Olds. Washington DC: National Center for Children in Poverty.

Roseth, C. J., Pellegrini, A. D., Dupuis, D. N., Bohn, C. M., Hickey, M. C., Hilk, C. L. \& Peshkam, A. (2008). Teacher intervention and U.S. preschoolers' natural conflict resolution after aggressive competition. Behaviour, 145, 1601-1626.

Ross, H. S. \& Conant, C. L. (1992). The social structure of early conflict: Interaction, relationships, and alliance. In C. U. Shantz \& W. W. Hartup (Eds.), Conflict in Child and Adolescent Development (pp. 153-185). New York: Cambridge University Press.

Runions, K. C. (2014). Reactive aggression and peer victimization from pre-kindergarten to first grade: Accounting for hyperactivity and teacher-child conflict. British Journal of Educational Psychology, 84(4), 537-555.

Sipahioğlu, E. (2008). Ilköğretim 1. kademesinde sınıf içi istenmeyen öğrenci davranışları ve çözüm önerileri (Narlıdere Örneği) [In-class undesirable student behaviors in Level1 elementary education and suggestions for solution (Case of Narlidere)]. Unpublished Master's Thesis, Beykent University Institute of Social Sciences: İstanbul. 
Seda ATA | Seda KARAYOL

Smith, B. \& Fox, L. (2003). Systems of service delivery: A synthesis of evidence relevant to young children at risk of or who have challenging behavior. Tampa, FL: Center for Evidence-Based Practice: Young Children with Challenging Behavior, University of South Florida.

Spivak, A. L. \& Farran, D.C. (2016). Predicting first graders' social competence from their preschool classroom interpersonal context. Early Education and Development, 27(6), 735-750.

Stormont, M., Beckner, R., Mitchell, B. \& Richter, M. (2005). Supporting successful transition to kindergarten: General challenges and specific implications for students with problem behavior. Psychology in the Schools, 42(8), 765-778.

Strauss, A. \& Corbin, J. (1998). Basics of Qualitative Research: Techniques and Procedures for Developing Grounded Theory (2nd ed.). Thousand Oaks, London, New Delhi: Sage Publications.

Sugai, G. \& Horner, R. (2002). The evolution of discipline practices: School-wide positive behavior supports. Child \& Family Behavior Therapy, 24(1-2), 23-50.

Şahin, i. T., Tantekin-Erden, F. and Akar, H. (2011). The Influence of the Physical Environment on Early Childhood Education Classroom Management. Eurasian Journal of Educational Research, 44, 185-202.

Thompson, B. (2009). Disruptive behaviors in Barbadian classrooms: Implications for universal secondary education in the Caribbean. Journal of Eastern Caribbean Studies, 34(3), 39-58.

Thompson, R. A. \& Goodman, M. (2009). Development of self, relationships, and socioemotional competence: Foundations for early school success. In O. A. Barbarin \& B. Wasik (Eds.), Handbook of Child Development and Early Education: Research to Practice (pp. 147-171). New York, NY: Guilford Press.

Uysal, H., Altun A., S. and Akgün, E. (2010). Okulöncesi Öğretmenlerinin Çocukların İstenmeyen Davranışları Karşısında Uyguladıkları Stratejiler [Strategies Used by Preschool Teachers against Undesireable Behaviors of Children]. Ilköğretim Online, 9(3), 971-979.

Yıldırım, A., Şimşek, H. (2013). Sosyal Bilimlerde Nitel Araştırma Yöntemleri [Qualitative Research Methods in Social Sciences] (Extended 9th Edition). Ankara: Seçkin Yayınevi.

Yıldız, B. (2006). Sınıf öğretmenlerinin istenmeyen davranışlarda kullandıkları önleyici yaklaşımlar ve bu yaklaşımların etkililiğine ilişkin öğretmen ve öğrenci görüşleri [Preventive approaches used by classroom teachers to undesirable behaviors and teacher 
and student opinions on the effectiveness of these approaches]. Unpublished Master's Thesis, Abant Izzet Baysal University Institute of Social Sciences: Bolu.

Yin, R.K. (2009). Doing Case Study Research. 4th ed. Thousand Oaks, CA: Sage.

Yüksel, A. (2006). Illköğretim 1. kademede 1., 2. ve 3. sınıflarda istenmeyen öğrenci davranışlarına ilişkin öğretmen gözlem ve görüşleri [Teacher observations and opinions on undesirable student behaviors in 1st, 2nd, and 3rd grade in Level-1 elementary education]. Unpublished Postgraduate Thesis, Afyon Kocatepe University Institute of Social Sciences, Afyon. 